\title{
Trends and Changes in Training History Teachers in Academia, and Its Interface With the Israeli Education System
}

\author{
Yitzhak Cytrin \\ Correspondence: Dr. Yitzhak Cytrin, Head of History Department at the Shaanan Teachers' College in Haifa, Israel.
}

Received: March 1, 2018

Accepted: March 29, $2018 \quad$ Online Published: March 31, 2018

doi:10.11114/jets.v6i5.3150

URL: https://doi.org/10.11114/jets.v6i5.3150

\begin{abstract}
This article aims to examine the difficulties, misgivings, and criticism that exist in academia and the field of education, regarding creating history curricula relevant and significant to twenty-first century society and individuals; how compulsory history curricula can be suited to the methodology and didactics of training students as history teachers, and suggest several solutions to the issues discussed.

The structure of knowledge approach in the discipline of history is problematic, and creates a complex challenge regarding preparing history students as teachers of the future. This is because this discipline represents, to a great extent, the wider fields of the humanities and social sciences which are very difficult to integrate into the school educational process.

Historical research and the education system have different goals. The historian strives to clarify "historical questions", meaning issues from the past with the perspective of their having certain relevance to the future. In contrast, the education system seeks to shape the student's worldview and provide him with significant tools for coping with the challenges of the twenty-first century, as part of the "toolbox" that the education system believes will serve as a basis for the student's preparation to be a useful individual in society and for himself.

In light of the weight of history in teaching values, based on reliable facts gained from historical research, the main role that should be given to teaching the subject is to teach critical thinking. The ability to understand history in its framework of reference, meaning, understanding change and the environment, needs to be developed. Likewise, it is necessary to arouse and develop the judicious use of facts and drawing conclusions. Learning history can, and must, take place both experientially and logically. Presenting the "historical story" alongside the "cognitive-critical" approach must be the primary "pedagogy" when instilling students with teaching skills.

Achieving history curriculum goals is greatly dependent on the teaching and evaluation methods, and how well teachers succeed in bringing their students to be active and involved in the learning process. Therefore, a variety of teaching strategies must be employed, in the spirit of the constructionist approach. Training teaching students requires a variety of pedagogic methods and methodological approaches, and teaching literacy for strategies for interdisciplinary teaching methods, integrative learning, and use of digital technologies.
\end{abstract}

Keywords: history as a discipline, student training, teaching history

\section{Introduction}

Why should we teach history? Is it not an outdated subject, like Latin, or some classical studies that no longer feature in the list of compulsory subjects to be taught in high schools? In light of the opinions and attitudes about "the end of history", what value is there to knowing about the past when we need to prepare our students for the world of tomorrow? What relevance does history teaching have to our lives, as a society, and in particular as individuals in our community at the beginning of the twenty-first century? Regarding the complex nature of history and its teaching, see Denos and Case (2006), and Harrari $(2011,2015)$.

Does studying history as a discipline in the colleges of education, and training students to teach history in schools - two not necessarily overlapping planes - have a value? Is training students to teach history even viable? And if so, how can we prepare history students for their role as teachers and potential researchers? Wineburg (2001).

This article examines the difficulties, misgivings, and criticism that exist in academia and the field of education, regarding creating history curricula relevant and significant to twenty-first century society and individuals; how 
compulsory history curricula can be suited to the methodology and didactics of training students as history teachers, and suggests several solutions to the issues discussed.

\subsection{What Is History?}

The essence of the discipline of history will be examined. No attempts have been made to pretend to unequivocally define something controversial among historians themselves. Rather, the article presents several opinions that demonstrate the complexity of the field. The history discussed includes all areas of human activity including political, religious, social, economic, cultural, and technological activities.

Michael Heyd (1991) argues that the story once again occupies a primary place in writing history, whereas in recent decades it has been influenced by the various social sciences. It is true that modern historiography does not accept one defined and continuous story as the exclusive truth, but rather suggests different stories and examines the objectivity of each one.

The historian Ernst Cassirer (1976) defines history as dealing with the essence of our existence as a human society, with the purpose of understanding the basis of our existence, and as a means of constructing universal human awareness. Fritz Stern (1973), in his important book on the development of modern historiography, defines involvement with history as a pleasant human task connected with researching all past human activities. Yaacov Shavit (1984) believes that history - organizing cultural knowledge about the past with a connection to the present - tries to reconstruct a continuum of events and grant them order and significance. In this way pictures of the past are created to be used by the collective awareness.

Israel Kolatt (1976) believes there is a far-reaching pretension in defining the study of history. History wishes to discuss the development of human society, not as one of its branches, but in its entirety; while the sociologist or anthropologist wishes to discuss defined branches or clear and determined research methods in human development, the historian wants to include the entire situation and the individual, formational, and coincidental event. The historian seeks to discover the past birth of allegiances and identities that continue to exist in the present and how they are connected to social groups. He wishes to describe the moving, rather than static, historical description, not only by conceptually defining the existing situation but also by describing the flow and changes.

The study of modern history, written in a scientific model, begins with Voltaire. Since then, historiography has changed its form many times. During the eighteenth century, historians wished to view the story of humanity as the development and creation of humanity rather than as a Godly decree, in line with the humanistic philosophies that characterized that period that sought to bring about recognition of the unity of all humanity. Nineteenth century historiography focused on nationalist orientation, and believed in its ability to rationally solve the long-term codes and trends of behavior or historical patterns. In contrast, twentieth-century historians divided history into sub-fields, such as military, social, economic, political, and scientific history. This change made historical research more precise, but also more limited (Stern, 1973; Kolatt, 1976).

After the Second World War, historiography focused on social and economic history and essentially became quantitative history, based more on statistical data than texts. Branches of history linked to the social sciences developed, such as psychohistory - that attempted to emphasize the basic structures and gradual processes in history, rather than changing events (Heyd, 2001).

It emerges, therefore, that dealing with history at all is problematic, since it is a field that has undergone many historiophilosophical revolutions, and those involved with the subject cannot agree on one, permanent, methodology. The common denominator of the different methods - only some of which were brought above - is the friction between "the individual fact" and creating a general framework and presenting the "historical process". The historian will always look for the general significance reflected in the individual facts.

\subsection{The "Friction" Between Training the Student to Be Both a "Historian" and a "History Teacher"}

Historical research and the education system have different goals. The historian aims to clarify "historical questions", meaning issues from the past with the perspective of their having certain relevance to the future. In contrast, the education system seeks to shape the student's worldview and provide him with significant tools for coping with the challenges of the twenty-first century (Michman, 1998). Moreover, the structure of knowledge approach in the discipline of history is problematic. This is because it represents, to a great extent, the wider fields of the humanities and social sciences, which are very difficult to integrate into the school educational process. An additional problem hidden in the history curricula for the various sectors - State secular, State Religious, ultra-Orthodox, and non-Jewish - is that each curriculum has different goals and objectives derived from the values the sector wishes to instill in the students (Zimmerman, 1991).

Understanding of the historian's work has developed at an accelerated rate since the nineteenth century from extreme 
positivism - "the historian describes history as it was" to extreme relativism, in the post-modern age, meaning "there is no one positivistic truth" - everything is a narrative, and in essence, every historian presents a particular ideological or political-class narrative (Stern, 1973; Lorenz, 1994).

The historian is of course limited by anchors of facts and figures that can be professionally criticized. However, the choice of historic research object originates in the researcher's subjective interest. In contrast, the historian will not set himself the goal of supporting and glorifying a particular outlook in advance, while intentionally ignoring everything contradicting the thesis he presents in his study (Michman, 1998). However, in the modern nationalist state, the education system's interest is shaping a person and equipping him with a "toolbox" to enable him to integrate and operate within society upon completing his studies. This means the education system will set "value-based" educational targets and goals derived from each stream's sectorial ideology, and direct history teaching targets towards these values (Kodesh, 1997). Therefore, the history curricula are essentially an interpretation dictated "from above" to the students.

\subsection{The Problems and Importance of Teaching History in Light of Twenty-First Century Challenges}

There is no educational system that does not engage in profound arguments about "shaping the path". The education system attempts to create a "toolbox" that includes some of the beneficial purposefulness that must be relevant to the world of the student. This purposefulness is the base for the contradiction between the principles that guide the historic-research approach, and the goals of history teaching in schools.

\subsection{The Problems With Teaching History}

The pedagogue Paulo Freire, one of the foremost thinkers in the history of world pedagogy, determined that education is always political, and the social elite utilize schools to advance their own agenda. The modern nationalist state controls the education systems, and shapes the narrative through supervision of its study content (Freire, 1970). This situation also exists in the State of Israel where history teaching has become a political battlefield. Schools and textbooks, particularly history ones, affect the construction of student identity, and serve as agents of reproduction for knowledge and ideology (Apple, 1986).

There is discomfort, to say the least, regarding history curricula and textbooks in Israel. Examining history textbooks from 1948-2006 raises fundamental questions - which topics were expanded and emphasized? Which were suppressed or disappeared from the curricula and textbooks? What were the curriculum changes, and how were they enlisted to shape the collective memory and consciousness (Kizel, 2008)?

Researchers estimate that few changes were introduced over the years in the high school history curricula, despite the existential changes that have entered the State of Israel's social and official narrative during recent decades (Yogev, 2005). The battle regarding history teaching, as reflected in the final controversy surrounding the new textbooks, is essentially a cultural war on the "collective memory," and a mirror image of the deep divide in Israeli society (Yogev \& Nave, 2000).

Development of history curricula in the past decades shows a trend expressed in increasing recognition of cultural and social pluralism, with the Ministry of Education's policy being to help minorities preserve their cultural and national identity as an integral part of Israeli society (Mathias, 2003). The purpose of this trend is to create solidarity in society, while also helping individuals and communities develop their true identity. However, implementation of this policy has created a controversy in structuring the Israeli identity, essence, and boundaries (Mathias \& Tsabar Ben-Yehoshua, 2004). This policy has contributed to frequent changes in what was emphasized in the curricula, and great tension among history teachers, whether scholastic material should have global or localized orientation, and has made it difficult for teachers to shape an approach for appropriate glocalization that enables "dialogic learning" in the Israeli reality of the schisms that exist (Yemini \& Bornshtein, 2016).

In light of the complexity of the teaching goals, history teachers often have doubts about their educational role and mission, and fear using their influence excessively to shape their students' opinions, particularly during a time of fundamental public debate and undermining basic beliefs of Israeli society (Ginzburg, 1998). The more the topics can influence the historic identify and memory (Eilam, 1992), especially regarding such issues as Israeli nationalism and consciousness in State education, modernization and Mizrahi Jewry, the educational emphasis in teaching Jewish history in the State Religious sector, and ethnocentric as against multicultural approaches, the greater the teachers' doubts (Ben-Amos, 2002).

Teaching the Shoah and its significance are a real pedagogic challenge for teachers. The discussion regarding the questions and dilemmas emanating from the events of the Shoah and its teaching are complex: Is the Holocaust like any other historical event? Should we emphasize the uniqueness and singularity of the Shoah, or try and rank it among "similar cases", such as the Armenian genocide, so as to reach universal conclusions? (Schatzker, 1998). A stronger question concerns Holocaust denial altogether, particularly in Palestinian textbooks - in light of the continuing ethno-nationalist conflict (Alayan, 2016). 


\subsection{The Importance of History Teaching}

Historians themselves no longer refer to history as the key to understanding the present by looking at the past with the intention of shaping the future. All the more so, studying history is no longer seen as a court for solving claims rooted in the past, such as historic rights to parts of the country, deciding ongoing nationalist disputes, preferring one ethnic narrative as representing the "historical truth". It is obvious that studying history is intended to contribute to building a strong factual infrastructure for events, but no more than that, due to the subjectivity of the historian who defines his research objective and presents the findings and conclusions of his historical research. Even the claim that recurring situations in public lives can be learned from history now seems utterly baseless (Kolatt, 1976). With regard to the significance and relevance of history, it is not unequivocally clear at the beginning of the twenty-first century - if so, why should it be taught?

Herewith, some answers and lines of thinking. Studying history is, first and foremost, a human task. The human needs to know about the past as a cultural creation that preceded written history and awareness, and certainly greatly preceded scientific history. The tradition of folktales regarding the source of human collectives, their common backgrounds, wars, and conquests, exists among every nation and in every language - its purpose is to explain the collective time of the human collectives. Man made an effort to stop the flow of change and maintain it with concepts of culture, science, artistic creations, and certainly historic tradition (Kolatt, 1976).

Many historians argue that the basic reason for studying history is pleasure or study for its own sake (Kodesh, 1997). Sometimes a person enjoys shattering myths and setting the facts of the past as right, gaining pleasure in revealing the truth. There is also love and sympathy for researching earlier times. The primeval desire to investigate the genius, also contributes to human curiosity and researching history, like studying the past allows the revelation of causativeness rooted in the past for crises and/or events in the present (Stern, 1973).

History that deals with different cultures and societies in ancient and recent history discusses the study of the "other", who is different from us, and also - perhaps primarily - when it speaks of a sharp national and ongoing conflict, like that occurring in our region (Yogev, 2013). There is supreme human importance - particularly in a democratic-pluralistic society to understand and respect, even without agreeing with perspectives and opinions different to those we live by (Heyd, 1991).

History can promote the understanding that there is a basic similarity between people in every generation. Nurturing the understanding of mutual dependence between society and individuals during the development of the human race can point to universal emphases on humanity and influence how the present is seen (Yaoz, 1994). Therefore, teaching history can promote an approach of tolerance and multiculturalism and aid in deepening intercultural ties something of great importance in the pluralistic, polarized society in the State of Israel (Al-Haj, 2007).

Teaching ethnic history of groups and minorities can help their struggle for human rights and strengthen the concern for their psychosocial welfare since their narrative is given a "place of honor and recognition" in the curriculum of the majority society and/or social elites (Tartakovsky, 2010).

The relevance of studying history is in the dimension of change through which the learner is educated about the awareness of processes of change in human society. It is precisely in our times with their technological changes, and accompanying rapid and frequent political, social, and economic changes, that learning history is of great value. Such study strengthens skills for the learner, allowing him to understand the character of change in human society. These skills will allow a person living in modern society to form a balanced and critical view of his experiences (Heyd, 1991).

History also plays an important role in the service of society. Historical recognition sharpens the ability of the individual and society to judge and evaluate situations, unveil mysteries from the past and evaluate it as it actually happened. Researching the national truth regarding everything concerning leadership assessment - particularly charismatic and captivating leadership and how it is followed - is extremely important since historic experience teaches the significance of decisions made by leaders in the name of public interest and their cost in human life. The information provided by the historical examination is essential for spiritual and social life. This issue stands out due to the occasionally cynical use by some public figures of historic facts to prove their political claims, or reading or hearing media errors offering information based on a superficial study of the past (Stern, 1973).

History is extremely relevant to the younger generation who investigates its past and wishes to examine the values and loyalties formed and bequeathed by the previous generation by viewing those values and loyalties not only through the prism of that earlier generation but primarily examining whether they are still valid for them, too. The wish to examine the past and insert the human fate within the significant patterns that originate from the past and influence the present, motivates historical examination and testing (Kolatt, 1976).

Several comments belong here regarding the importance of teaching history from an educational viewpoint. The central 
question is to what extent our political values, sense of identity, and worldview are determined by the type of history we were taught at school. Undoubtedly, the Zionist ideology which forms part of Jewish identity, the historic fate of the Jewish people, its right to the Land of Israel, and the lessons of the Holocaust, are greatly influenced by the historical consciousness learned at school. Studying history undoubtedly serves as a vehicle for strengthening values.

In light of history's weight in teaching values, based on reliable facts learned from historical research, the main role that should be given to teaching the subject is to teach critical thinking. The ability to understand history in its framework of reference, meaning, understanding change and the environment, must be developed. Likewise, it is necessary to arouse and develop the judicious use of facts and drawing conclusions. Learning history can, and must, be both experiential and logical, with the balance changing along with the student's chronological age. It is self-understood that the younger the student, the more problematic the ideas of "historical time" with concepts of "duration" and "continuity" (Nadel, 1997), and the more teaching must give him skills for mastering "time" in accordance with his cognitive development (Frank \& Sarig, 1986). Undoubtedly, presenting the "historical story" alongside the cognitive-critical approach is likely to arouse interest in both the young child and adolescent, and should it be offered in the correct way but not only frontally.

\subsection{Educational Methods and Strategies in Teacher Training, in Conformance With the Ministry of Education's Compulsory Curriculum}

Several teaching strategies will be offered in the spirit of the constructionist approach, on which the history teacher training program in teaching colleges should be based.

Integrative Learning

It strengthens chronological mastery ability which the student will use to address selected historical topics and develop the skills to create generalizations that indicate the historical process (Rauner, 1995).

Learning through Research

It strengthens rationalist, creative, critical, and reflective historical thinking regarding the topics. While learning, the students will experience discussion of complex historical problems that involve analysis of primary sources and information from secondary ones (Schremer, 2004).

\section{The Study Discourse}

After the dialogue regarding knowledge learned, the students will attempt to criticize and challenge accepted explanations for historical processes (Shachar \& Schwarz, 2016).

Training Independent Researchers

It includes acquiring skills in quantitative and qualitative research characteristics, and the advantages of combining them. Using research tools will bolster the students' abilities as future independent researchers (Kaniel, 2014).

\section{Learning Outside the Classroom}

It intensifies the learning experience, exposes the students to geographical and environmental aspects and deepens their knowledge of the topic, e.g. field trips to historic sites in Israel and the study pilgrimage to Poland (Lev, 2007), visiting historic museums (Keren, 1998) and the students setting up exhibitions at the college about historical topics, such as Holocaust Remembrance Day and Memorial Day for Israel's Fallen Soldiers (Alderoqui Pinus, 2014).

\section{Interdisciplinary Teaching}

It is characterized by associations, relevance, and reflecting real opinions and helping understand complex reality. Interdisciplinary teaching that combines learning history and other knowledge domains includes social, cultural, and intellectual issues focused on humans and their lives, and therefore, this approach is considered "significant learning". The interdisciplinary approach is powered by the belief that one knowledge domain cannot represent the changes occurring in the world of information. The fact that information in the twenty-first century rapidly changes means information is temporary, and contextual rather than objective. Therefore, it is considered artificial and limiting to rely solely on individual knowledge domains.

Obviously, this is not a simple task at all. However, it using several suggestions are brought here that can be implemented while training history teachers in the colleges so that history teaching can be developed within the wider context of the humanities or classical studies by exposing students to studying historical issues in a cultural-spiritual context (Feingold, 1991). Teaching of the "historical-literary story" can be integrated into the history teacher's toolbox. In addition, combining history and literature can be accepted as something natural rather than artificial (Vansover, 2015). Thus, teaching written and oral Torah can also be integrated with history teaching (Hanauer, 1997). Combining geography and history is seen as totally natural since it enables strengthening the geographic background as a base for understanding historical processes (Meir, 1982). 


\subsection{Teaching Methodological Skills to History Teaching Students}

Here are several brief examples of teaching skills that are important to impart to the students during their training.

Simulation Games: "Role Play" and Holding a Historical Trial

These methodologies offer the possibility of gaining familiarity with the spirit and understanding of the times and embody the principle of "significant learning" that contributes to deepening the learners' understanding and developing "higher order thinking strategies" since this methodology invites consolidating opinions and explained viewpoints while debating with others based on factual claims and their analysis.

Folktales as a Source for History Teaching

Passages from sources that include folk traditions can be used as a source for understanding the spirit of the times.

Historical Photography - As a Source for Understanding History

Photographs (including historic aerial photographs) and illustrations of well-known regions can be used to compare them with their present appearance and draw conclusions regarding the historic process as times change.

Historical Maps

It includes documenting geographic, state, economic, and other regions. Political maps can be used to see changes between periods.

Synchronic Tables of Events

They can be used to learn about the place of the historic event in the context in which it occurred.

Biographies, Autobiographies, and Books of Memories

These are written about and by important figures and can be used to gain familiarity with the "historic figure" and discuss its influence on historic processes.

"Identity Card" or "Family Album"

They can be used to draw conclusions from events that happened to individuals and understand the patterns and systems of historic events studied as part of the curriculum.

\section{Watching Historic Movies or Documentary Films}

Documentary films can serve as historic sources and by watching them the learner can have his interest in the historical material piqued since they can help with a discussion about the events shown in the films and contribute to intensifying the experiential dimension of the learning.

Use of Digital Technology

It includes teaching computer literacy and information, intelligent and supervised use of websites. Teaching skills for working in a technological environment will serve the operation of a range of software and applications, help structure research processes for creating and editing materials, aid in advancing sharing of information, all of which are suited to the twenty-first century.

The aforementioned are only a few of the wide range of teaching methods. It is always important to stress to the students the need to ensure the quality of the material and present it in a proportional, balanced, and considered way as part of teaching strategies necessary to vary teaching process, strengthen the learning experience and aspire to "higher order thinking" teaching.

\section{Summary and Conclusions}

Historical research and the education system have different goals. The historian strives to clarify "historical questions" - issues from the past with the perspective of their having certain relevance to the future. In contrast, the education system seeks to shape the student's worldview and provide him with significant tools for coping with the challenges of the twenty-first century as part of the "toolbox" that the education system believes will serve as a basis for the student's preparation to be a useful individual in society and for himself.

The structure of knowledge approach in the discipline of history is problematic and creates a complex challenge regarding preparing history students to be teachers of the future. This is because this discipline represents, to a great extent, the wider fields of the humanities and social sciences which are very difficult to integrate into the school educational process.

An additional problem hidden in the history curricula in today's State of Israel is that the different sectors (State secular, State Religious, ultra-Orthodox, and non-Jewish) each have different curricula with their own goals and objectives 
derived from that sector's particular values. Thus, from the outset, training students as future teachers includes the danger of "ideologically biased training" and perhaps even the danger of intending to train for "indoctrinating teaching" which utterly contradicts the teaching of history as a critical scientific discipline.

The challenge to train students without getting into the dangers described above is complex and requires careful judgment regarding syllabus content and its conformance to the curriculum, together with training methods during the students' teaching practice, and guidance for the pedagogical instructors and mentors.

In light of the weight of history in teaching values, based on reliable facts gained from historical research, the main role that should be given to teaching the subject is to teach critical thinking. The ability to understand history in its framework of reference, meaning, understanding change and the environment, needs to be developed. Likewise, it is necessary to arouse and develop the judicious use of facts and drawing conclusions. Learning history can, and must, take place both experientially and logically. Presenting the "historical story" alongside the "cognitive-critical" approach must be the primary "pedagogy" when instilling students with teaching skills.

Achieving the curriculum goals is greatly dependent on the teaching and evaluation methods, and how well the teachers succeed in bringing their students to be active and involved in the learning process. Therefore, a variety of teaching strategies must be employed in the spirit of the constructionist approach. Some strategies have been proposed in this article, together with a number of teaching methods and teaching skills that can be used as a base for training history students as effective and significant teachers.

History teaching presents a complex challenge as an academic discipline, particularly during teacher training. The very idea of history being a scientific discipline is controversial among historians themselves (Ben-Sasson, 1969). The postmodernist historians negate the idea of history being a scientific-critical discipline. Haydan White (1973), who is considered the most important and influential postmodern historian in the academic world, argues that a historian cannot attain "researching the truth", but can only construct history as a narrative. This minimizes the difference between history and literature. Therefore, he argues that history is not a scientific-critical discipline.

Elazar Weinryb (2003) also believes that historical research does not reflect reality as it actually was. We can learn from a historian's writings only about his personal intentions, historiosophical approach, and beliefs. It emerges that the historian interprets the event he discusses and assigns its significance in accordance with his subjective beliefs and position. Consequently, the scientific objectivity of the history discipline is flawed in the first place. In which case, what value does this discipline have?

It is self-understood that postmodernist beliefs are not accepted by most historians for their own reasons. However, it is impossible to ignore their arguments regarding the subject's lack of scientific relevance. Therefore, there is obvious difficulty and challenge in defining the goals for history teaching and creating a syllabus that includes agreed-upon narratives, in a multinational and split society.

\section{References}

Alderoqui, P. D. (2014). Considerations and dilemmas when setting up an exhibition: The viewpoint of educators. Platforma, January. [Hebrew] Retrieved from http://www.israelmuseum.org.il/platforma

Al-Haj, M. (2007). A curriculum between conflict and peace: The teaching of history in Jewish and Arab schools in Israel. In M. Al-Haj \& R. Mielke (Eds.), Cultural diversity and the empowerment of minorities: Perspectives from Israel and Germany (pp.61-76). New York: Berghahn.

Apple, M. W. (1986). Teachers and texts: A political economy of class and gender relations in education. New York: Routledge and Kegan Paul.

Ayalan, S. (2016). The Holocaust in Palestinian textbooks: Differences and similarities in Israel and Palestine. Comparative Education Review, 60(1), 80-104. https://doi.org/10.1086/684362

Ben-Amos, A. (Ed.). (2002). History, identity, and memory: Images of the past in Israeli education. Tel-Aviv: Ramot. [Hebrew]

Ben-Sasson, H. H. (Ed.). (1969). The history of the Jewish people, Vol. 1 - General introduction. Tel-Aviv: Dvir. [Hebrew]

Cassirer, E. (1976). An essay on man: An introduction to a philosophy of human culture. New Haven: Yale.

Denos, M., Case, R., Seixas, P. C., \& Clark, P. (Eds.). (2006). Teaching about historical thinking - A professional resource to help teach six interrelated concepts central to students' ability to think critically about history. Vancouver: University of British Columbia: The Critical Thinking Consortium.

Eilam, Y. (1992). History teaching as a test case for values. Yedion Morey Historia, 3-4, 17-24. [Hebrew] 
Feingold, B. (1991). Teaching literature as history. Mehalkhim behinukh, behoraah, uvehakhsharat morim, 190-197. [Hebrew]

Frank, A., \& Sarig, A. (1986). Problems in children understanding historical times. Hahinukh Hameshutaf, 38(121), 83-96. [Hebrew]

Freire, P. (1970). Pedagogy of the oppressed. New York: Herder and Herder.

Ginzburg, H. (1998). The teacher, teaching history, and ethics: Ethical dilemmas for history teachers (Unpublished master's thesis). Tel-Aviv: Tel Aviv University. [Hebrew]

Hanauer, D. (1997). Student teachers' knowledge of literacy practices in school. Teaching \& Teacher Education, 13(8), 847-862. https://doi.org/10.1016/S0742-051X(97)00024-3

Harari, Y. N. (2011). Sapiens: A brief history of humankind. Or Yehuda: Dvir. [Hebrew].

Harari, Y. N. (2016). Homo Deus: A brief history of tomorrow. London: Harvill Secker.

Heyd, M. (1991). Is there a future to the study of the past? Alon Morei Historia, 3-4, 12-16. [Hebrew]

Kaniel, S. (2014). Integration of qualitative and quantitative research in the researcher's toolbox. Oreshet, 5, 257-284. [Hebrew]

Keren, N. (1998). The institutions for commemorating the Holocaust in Israel as educational agents. Hahinukh Vesvivo, 20, 19-24. [Hebrew]

Kizel, A. (2008). Subservient history: A critical analysis of history curricula and textbooks in Israel 1978-2006. Tel-Aviv: Mofet Institute. [Hebrew]

Kodesh, S. (1997). Lifelong education in Jewish sources: Principles and methods. International Journal of Lifelong Education, 16(6), 535-549. https://doi.org/10.1080/0260137970160606

Kolatt, I. (1976). The study and the researcher of the history of the yishuv and Zionism. Cathedra, 1(3-35). [Hebrew]

Lev, M. (2007). Teenage pilgrimages to Poland: A pilgrimage to the memory of the Holocaust. In S. Romi \& M. Schmida (Eds.), Nonformal education in a changing reality (pp. 433-449). Jerusalem: Magnes. [Hebrew]

Lorenz, C. (1994). Historical knowledge and historical reality: A plea for 'internal realism'. History and Theory, 33(3), 297-327. https://doi.org/10.2307/2505476

Mathias, Y. (2003). Teaching history in the Israeli education system - continuity and change. In Y. Dror, D. Nevo, \& R. Shapira (Eds.), Changes in education: Outlines for educational policy in Israel for the $21^{\text {st }}$ century (pp. 163-191). Tel-Aviv: Ramot. [Hebrew]

Mathias, Y., \& Tsabar Ben-Yehoshua, N. (2004). Curriculum planning reforms and the forging of Israeli identity. Megamot, 43(1), 84-108. [Hebrew]

Meir, A. (1982). The urgency of teaching history and philosophy of geography. Professional Geographer, 34(1), 6-10. https://doi.org/10.1111/j.0033-0124.1982.00006.x

Michman, D. (1998). Zionism is not just 'Nationalism'. Panim, 6, 61-67. [Hebrew]

Nadel, N. (1997). The connection between time and teaching it in history. Etgar: Leket Yozmot Hinukhiot, 5, 25-58. [Hebrew]

Rauner, G. (1995). Interdisciplinary curricula based on the topic method in the educational institutions of Hakibbutz Haartzi, 1931-1952. Tel-Aviv: Tel Aviv University, School of Education. [Hebrew]

Schatzker, C. (1998). The teaching of the Holocaust: Dilemmas and considerations. In Y. Rappel (Ed.), Memory and awareness of the Holocaust in Israel (pp. 87-92). Tel-Aviv: Ministry of Defense. [Hebrew]

Schremer, O. (2004). Historical literacy and critical sensibility. Ramat Gan: Bar-Ilan University. [Hebrew]

Shachar, N., \& Schwarz, B. B. (2016). On tensions and opportunities in combining dialogic and critical aspects in argumentative activities in the history classroom. Megamot, 50(2), 277-314. [Hebrew]

Shavit, Y. (1984). Hebrews and Phoenicians: An ancient historical image and its usage. Cathedra, 29, 173-191. [Hebrew]. https://doi.org/10.1080/13531048408575861

Stern, F. (1973). The varieties of history: From Voltaire to the present. New York: Vintage.

Tartakovsky, E. (2010). Teaching ethnic history in school: Experience from the West and the case of Jewish history in the Former Soviet Union: A literature review. International Journal of Jewish Education Research, 2, 81-96. 
Vansover, Y. (2015). Three heroes, two stories, one insight: Literature marches into history class. The Social Studies, 106(6), 245-255. https://doi.org/10.1080/00377996.2015.1072081

Weinryb. E. (Ed.). (2003). Postmodernism and history: A selection of articles. Tel-Aviv: The Open University of Israel. [Hebrew]

White, H. (1973). Metahistory: The historical imagination in nineteen-century Europe. Baltimore and London: The Johns Hopkins University Press.

Wineburg, S. (2001). Historical thinking and other unnatural acts: Charting the future of teaching the past (Critical perspectives on the past). Philadelphia: Temple University Press.

Yaoz, H. (1994). Values and their reflection in the educational disciplines of literature and history. Iyunim Behinuch, 59/60, 367-372. [Hebrew]

Yemini, M., \& Bornshtein, Y. (2016). The global-local negotiation: Between the official and implemented history curriculum in Israeli classrooms. Globalisation, Societies and Education, 14(3), 345-357. https://doi.org/10.1080/14767724.2015.1123086

Yogev, E. (2005). History textbooks and curricula - The order of heritage and critical history. In H. Gur (Ed.), The militarization of education (pp. 146-166). Tel-Aviv: Bavel. [Hebrew]

Yogev, E. (2013). The pedagogy of subversion in history education in conflict-ridden areas. Journal of Peace Education, 10(1), 51-66. https://doi.org/10.1080/17400201.2012.721093

Yogev, E., \& Nave, E. (2000). Learning through dialogue in a time of national identity in transition: The debate surrounding the new history textbooks. Zmanim, 72, 4-19. [Hebrew]

Zimmermann, M. (1991). The structure of knowledge. In M. Silberstein (Ed.), The structure of knowledge in curriculum planning (pp. 24-31). Jerusalem: Ministry of Education. [Hebrew]

\section{Copyrights}

Copyright for this article is retained by the author(s), with first publication rights granted to the journal.

This is an open-access article distributed under the terms and conditions of the Creative Commons Attribution license which permits unrestricted use, distribution, and reproduction in any medium, provided the original work is properly cited. 